Article

\title{
Should CRISPR Scientists Play God?
}

\section{Ted Peters}

GTU/CTNS, 2400 Ridge Road, Berkeley, CA 94709, USA; tedfpeters@gmail.com

Academic Editor: Noreen L. Herzfeld

Received: 8 February 2017; Accepted: 5 April 2017; Published: 7 April 2017

\begin{abstract}
Will CRISPR usher in a new era of Promethean overreach? CRISPR makes gene editing widely available and cheap. Anti-play-god bioethicists fear that geneticists will play god and precipitate a backlash from nature that could be devastating. In contrast to the anti-play-god bioethicists, this article recommends that laboratory science invoke the Precautionary Principle: pause at the yellow caution light, but then with constant risk-assessment proceed ahead.
\end{abstract}

Keywords: CRISPR; Cas9; Prometheus; play god; stem cells; bioethics; germline intervention; Precautionary Principle

The year 2016 witnessed the World Premier of Liam Scarlett's ballet interpretation of Mary Shelly's Frankenstein: Or, The Modern Prometheus. The San Francisco Ballet's Encore says, "both book and ballet tell a disturbing, tragic tale about the consequences of abandonment, the risks of tampering with the creation of human life, and, most of all, the power of love, both given and withheld" (San Francisco Ballet 2017, p. 31). Will CRISPR gene editing lead our next generation into a Promethean if not Frankensteinian tragedy?

Sun Microscystems Bill Joy feared such a tragedy in the year 2000 when he wrote, "Our most powerful 21st-century technologies-robotics, genetic engineering, and nanotech-are threatening to make humans an endangered species" (Joy 2000). Joy warned that bio-machines smarter than we Homo sapiens would supersede us and then eliminate us. Where Joy was negative, today's transhumanists are positive. Super-biology will lead us to super-intelligence, and super-intelligence to a new post-human species. "Let us cast aside cowardice and seize the torch of Prometheus with both hands," says Transhumanist Manifesto author Simon Young (Young 2006, p. 40). Some fear Prometheus, while others greet the Greek Titan with open arms.

The Promethean hubris of the present generation to create super-intelligence is destined to overreach, to put in place the very mechanisms for our own demise. When we humans play god, nature will retaliate and make us suffer for it. So goes the Promethean myth. So goes the argument of anti-play-god bioethicists. This is not my position. Yet, it is a position repeatedly voiced when the subjects of genomics and genetic engineering are brought up.

Does the Promethean myth apply to gene editing with CRISPR technology? The alarm is already sounding. Modern Prometheus is the book title for a light treatment of otherwise heavy science. Science writer Jim Kozubek prophesies that "we will rewrite our own genetic code" (Kozubek 2016, p. 63). Although to date theologians have been oh hum about CRISPR, at least one religious spokesperson, Jim Eckman, worries that genetic manipulation might violate the divine image in the human species. This means, ethically, that we should abandon the semi-mythical technological imperative due to fear of another myth, the Promethean myth.

Human civilization must critically examine the scientific (technological) imperative. Simply because society can pursue a particular medical, reproductive or genetic procedure does not mandate that it must! Especially in the area of genetics, "can" does not mandate "ought." The potential for power and control and its obvious abuse mandates an examination of this 
imperative. Perhaps with some of these procedures, such as gene editing, it would be wise to not do them at all. (Eckman 2015)

According to such anti-play-god bioethicists, the yellow caution light means stop, do not race ahead.

We bioethicists find ourselves at a cross roads. What color is the traffic light? The technological imperativists or positive Prometheans want to see a green light, to proceed with speed. The anti-play-god Prometheans want to see a red light, to keep all traffic stopped. The proceed-with-caution bioethicist looks both ways on yellow, but drives forward. I recommend the third.

In what follows I argue for the following: proceed with caution. Don't stop. Keep driving ahead while perpetually assessing the risk; watch out for pot holes and avoid swerving into a ditch. This applies to germline intervention as well as somatic genome editing therapy.

Methodologically, I recommend that we proceed with developing and applying CRISPR/Cas9 while invoking the Precautionary Principle (PP). There is no warrant either theologically or ethically for putting up a red stop light to halt this particular technology. Theologically, I observe this: human creativity belongs inherently to the imago Dei, because we are created by the God who does new things (Isaiah 65:17). Philip Hefner rightly describes the human being as God's "created co-creator" (Hefner 1993, pp. 35-42). Ethically, I observe this: human relationship to God and to one another belongs inherently to the imago Dei (Herzfeld 2002, p. 87), so human creativity must always be thought of in terms of our relationship to self, God, and the world. The implication is this: if gene editing has the potential for improving human health and if gene drive has the potential for restoring the health-giving fertility of our natural environment, then the divine image of God at work in us will lead us to toward embracing CRISPR's benefits. If we think of human society as the divine image on Earth, then our creative advance in human health and ecological health through advancing medical technology would be a morally fitting expression of that divine image.

\section{A Conflict of Myths in the Heart of Science}

Two myths are competing with one another to grab the attention of the bioethicist, the green light myth of the technological imperative - that is, Prometheus positively interpreted - and the red light myth of anti-play-godism - that is, Prometheus negatively interpreted. The technological imperative is known commonly by its moral command, "if we can do it, then we should do it." The Promethan myth with its heir, Victor Frankenstein, frequently leads to a counter proscription, "thou shalt not play god."

The term myth here refers specifically to a conceptual set of presuppositions which frames a domain of discourse; a myth provides a screen or strainer through which information is filtered before it gets formulated. This definition of myth differs from other definitions such as (1) myth is a false story or (2) myth is an account of creation. At the intersection of science and culture, (3) a myth is a conceptual set, a worldview, a persistent framework for interpreting new experience (Peters 2017, pp. 96-97). Regarding CRISPR, the technological imperative partners with the positive interpretation of Prometheus whose hubris or pride led him to steal fire from the gods, while the anti-play-god lesson to be learned from the Promethean myth stands counter.

What is the technological imperative? Ask the super geeks. "The concept that new technologies are inevitable and essential and that they must be developed and accepted for the good of society. This philosophy is naturally promoted by super geeks in high-tech companies" (PC Magazine 2017). The technological imperative and the positive embracing of Prometheus lead to the same moral conclusion: if we can do it, let's do it. The light is green. Proceed with haste. This technological imperative is a myth, an ethical framework which keeps society on an accelerating treadmill toward ever advancing progress for the very sake of progress itself.

The counter to the technological imperative is the Promethean myth with its negative commandment: thou shalt not play god. The light is red. When applied to genetic engineering, the admonition against playing god means, "stop!" Leon Kass, former chair of the U.S. President's Council of Bioethics, puts up such a red stop light. "Not everyone cheers a summons to a post-human future. Not everyone likes the idea of remaking Eden or of man playing God" (The President's Council on Bioethics 2003) 
This phrase, "play god," sports at least three meanings. First, to play god means that scientific researchers investigate the inner sanctum of nature, revealing its previously hidden secrets. Second, to play god in the field of medicine is to wield the power of life and death; doctors become godlike to those on whom their very life depends. The third use of this term applies directly to genetic engineering: laboratory scientists play god when they alter life and influence the future evolution of the human species (Peters 2003, pp. 9-15; Peters 2005, pp. 124-25). From within the framework of the Promethean myth, bioethicists put up red lights by commanding: thou shalt not play god! This is not a theological commandment. Rather, it is derived from pagan mythology and applied to secular ethics. Because Zeus put a stop to Prometheus after the Titan had stolen fire from the gods, some of today's ethicists want to put a stop to the unbridled technologization of human life as we have inherited it from our evolutionary past.

Nearly a half century ago pioneer bioethicist Paul Ramsey warned us, "Men ought not to play God before they learn to be men, and after they have learned to be men they will not play God" (Ramsey 1970, p. 138).

More recently theologian Cynthia Crysdale has observed that the moral import of Prometheus' myth is to let nature take its course without technological intervention. "Most people who invoke this language envision a world of nature created by God, with its own distinctive sets of laws. Creation, according to this view, has a certain order instilled in it by God. The counterpart of the admonition that we ought not to play God is the positive injunction to 'let nature take its course'" (Crysdale 2003, p. 245). On the one hand, Crysdale shows respect for this anti-play-god red light. "The valid religious insight here lies in the recognition of the human tendency to overreach ourselves. The caution is against the hubris of the human spirit which assumes no limits." On the other hand, she argues that nature itself is not static but rather is changing and evolving with new things emerging. This means morally that we should take risks to advance the welfare and flowering of our species and our ecosphere. "In a world that is subject to emergent probability, the moral question becomes not whether to 'play God', whether to intervene in nature or not, but which kinds of interventions are legitimate and which kinds are not" (Crysdale 2003, p. 251). In short, take the risk and proceed with caution. "The best we can hope for is to set up new conditions of possibility for what might emerge, with due humility and caution" (Crysdale 2003, p. 256). Crysdale's traffic light is yellow, it appears to me.

Neither the technological imperative nor the Promethean myth are major scriptural themes. In its wisdom literature, the Bible comes close to warning us against Promethean hubris: (Proverbs 16:18) "Pride goes before destruction, and a haughty spirit before a fall." If Allen Verhey is correct in defining distinctively Christian bioethics-"Scripture is the measure, the canon, for any bioethics that would be Christian. Attention to scripture as somehow normative for bioethics is what makes Christian bioethics Christian" (Verhey 2005, p. 297)—then the Christian bioethicist is not mandated biblically either to adherence or repudiation of one or both myths. Discernment and sound judgment, however, demonstrate the wisdom of precaution.

With regard to CRISPR/Cas9, I would like to avoid such myths and proffer the following mandate: proceed with caution. Don't stop. Keep driving ahead, constantly assessing the harm-benefit risk. Watch out for pot holes and avoid swerving into a ditch.

\section{Remind Me: What Is CRISPR/Cas9 Again?}

Here is what you don't need to know. CRISPR stands for Clustered Regularly Interspaced Short Palindromic Repeats. What does this mean? In the past, our human genomes incorporated palindromic DNA repeats from bacteria and archaea which became an adaptive method for strengthening immune systems. The summary point to get is this: palindromic repeats of DNA base pairs provide targets for the geneticist to shoot at. 
The CRISPR archer shoots at these targets with Cas9 arrows. What's Cas9? It's an endonuclease capable of cleaving DNA. When combined with specific RNA in a system it can either insert or delete specific genetic sequences. If Cas9 is the arrow, the CRISPR archer can fire it to a specific target on a DNA strand, cut it, insert a prescribed sequence of nucleotides, and then re-connect the DNA strand. We call this "gene editing" for short.

Here is the upshot. CRISPR/Cas9 technology can be used for highly specific and convenient gene editing, either inserting sequences in target genes, deleting genes, or turning genes off. The overwhelming scientific consensus is that this technology will usher in an age of cheap and easy genetic manipulation. If we don't like the DNA nature has bequeathed us, we can employ CRISPR/Cas9 to edit it to our standards.

There is good reason for our scientists to applaud with vigor. According to Jennifer Doudna, one of the CRISPR pioneers, "The simplicity of CRISPR-Cas9 programming, together with a unique DNA cleaving mechanism, the capacity for multiplexed target recognition, and the existence of many natural type II CRISPR-Cas system variants, has enabled remarkable developments using this cost-effective and easy-to-use technology to precisely and efficiently target, edit, modify, regulate, and mark genomic loci of a wide array of cells and organisms" (Doudna and Carpentier 2014).

Some bioethicists, in contrast to the scientists, are not applauding. Arthur Caplan flashes the yellow caution light. "In addition to the discussion about human germline editing, CRISPR raises or revives many other ethical issues, not all of which concern only humans, but also other species and the environment" (Caplan et al. 2015). George Annas flashes the red light. "The core challenge is what the new technology means to the human species. Is it a technology that affects our understanding of humanity and opens the door to a neo-eugenics agenda that could threaten the survival of the species?" (Annas 2016). If CRISPR/Cas9 threatens species survival, then this warrants a red stop light.

A Promethean transhumanist will grin with glee at this. CRISPR/Cas9 could provide a tool in the tool box the transhumanist needs to build a more intelligent species, a post-human species which will leave today's Homo sapiens in the archives of evolutionary history. A bioethicist, on the other hand, trembles with fear that such playing god will lead to a recklessness that might put an end to our species before a superior one can emerge. How should we parse the issues?

\section{Therapeutic Editing of Somatic Cells}

Rather than threaten the existence of the human species, CRISPR/Cas9 shows promise for cancer researchers to improve human health and wellbeing. Everyday our immune system engages cancer threats with a defense. When the defense is compromised, cancer wins. On the front line is the T cell which, like Achilles, leads the immune system into the battle against cancer. In persons with metastatic non-small lung cancer for whom chemotherapy and radiation have failed, scientists have observed that $\mathrm{T}$ cells are sabotaged from within by a Quisling enzyme, PD-1. By sending CRISPR/Cas9 into these $\mathrm{T}$ cells, clinicians are hoping to snip out the PD-1 gene and liberate the T cell. The T cell should then triumph once again in the cancer siege (Cyranoski 2016; Kozubek 2016, p. 265; Couzin-Frankel 2016).

What we are talking about here is somatic genome editing therapy. As scientists move from theory to clinical application, we can foresee some applications to remove cells-such as blood or bone marrow cells-from a person's body, alter the genomes in these removed cells, and then return them to same individual. Because the edited cells would be outside the body (ex vivo), the success of the editing could be verified before the cells were replaced in the patient. Such ex vivo application of CRISPR/Cas9 technology reduces drastically any risk to the patient's safety.

That's ex vivo editing in the Petri dish outside the body. Such genome editing could also be performed directly in the body (in vivo) by injecting a genome-editing tool into the bloodstream or target organ. There is a risk: gene-editing tools introduced into the body might not find their target gene within the intended cell type efficiently (NASEM 2017, pp. 72-78). The result could be little or no health benefit to the patient, or perhaps even unintended harm. The risk of unintended consequence of in vivo editing is higher than that of ex vivo, prompting increased concern for the patient's safety. 
"Despite these challenges, however," say the ethicists studying CRISPR on behalf of the National Academy of Sciences, Engineering, and Medicine (NASEM), "clinical trials of in vivo editing strategies are already under way for hemophilia B and mucopolysaccharidosis I" (NASEM 2017, p. 4).

Safety and efficacy are routine bioethical concerns, and they apply here. Taking safety and efficacy into account, we note that no serious ethical argument is being made to proscribe somatic genome editing therapy (NASEM 2017, pp. 82, 105, 112). NASEM advocates proceeding with caution with somatic genome editing therapy.

\section{The Special Case of Germline Intervention}

Other prospects give bioethicists nightmares, however. Caplan (above) reminds us of previous bioethical debates over germline intervention (Peters 2003, pp. 145-58). With CRISPR/Cas 9, that debate is back.

The terms used during the era of the Human Genome Project in the 1990s were "germline modification" and "human inheritable genetic modification." Today, "gene editing" could be applied to animal germlines and human germlines, so once again the question arises: is this ethical? "Where ethicists become most concerned is when germ cells are the target of CRISPR. Any changes in the germ cells can be potentially passed down to future generations, essentially introducing those changes into the human population" (Novella 2015).

Here is the way NASEM formulates the issue.

The technology [of germline modification] is of interest because thousands of inherited diseases are caused by mutations in single genes. Thus, editing the germline cells of individuals who carry these mutations could allow them to have genetically related children without the risk of passing on these conditions...Germline editing is highly contentious precisely because the resulting genetic changes would be inherited by the next generation, and the technology therefore would cross a line many have viewed as ethically inviolable....Policy in this area will require a careful balancing of cultural norms, the physical and emotional well-being of children, parental autonomy, and the ability of regulatory systems to prevent inappropriate or abusive applications.... It would be essential for this research to be approached with caution, and for it to proceed with broad public input. (NASEM 2017, pp. 5, 93-99).

Let me parse the issue. What we are talking about is altering the genetic code in germ cells-in eggs or sperm-that will influence future generations of a given species. Scientifically and ethically, this sounds like a great idea. Suppose we would snip out of the germline the gene for Huntington's disease located on the short arm of chromosome 4. Huntington's is a neurodegenerative disorder leading to mental decline, dementia, uncontrollable body movements, anxiety, depression, and aggression. In 1993, Huntington's was traced to a mutation leading to a trinucleotide repeat- - that is, three DNA bases (cytosine-adenine-guanine, or CAG) get repeated multiple times ( . . CAGCAGCAG ... ). So, looking at this, it is reasonable to ask: Should we snip out this allele from the germ cells, so that all children born later will be free of the Huntington's gene? In fact, if scientists do this systematically, we might eliminate Huntington's disease from the human gene pool. And, further, if scientists should perform this task for, say, another 2000 genetically based diseases, then ... what?

Two decades ago, the bioethicists said, "Whoah!" Why? Are the bioethicists heartless? Do bioethicists want to see Huntington's patients suffer? No, that is not the reason. Their judgment was based on what we don't know. What we don't know is the long-term effect of such large-scale changes in the genome. Genes work with other genes and other DNA in delicate systems like Swiss watches, mutually influencing one another. To eliminate one set of gears in an old fashioned Swiss watch would cause it to self-destruct. Might this analogy apply to the human genome? We don't know yet. Without this knowledge, clinical geneticists cannot measure the risk. 
Without knowing the level of harm-benefit risk, the question arising among bioethicists is this: should we proceed to modify the germline in human beings (and plants or animals too)? On most days when such questions arise, the average bioethicist can get by with a single-word vocabulary. All he or she needs to do is pronounce the word "No," with emphasis, and the job is done. If a bioethicist were to say, "Yes" too often, he or she would be shunned by colleagues as having sold out to the industry.

I recommend we try this on for size: "Yes, but not yet." That's a longer sentence than merely the word, "No". "Yes, but not yet" might be the most appropriate ethical counsel we could offer to those geneticists attempting to ascertain the risk level of CRISPR editing.

\section{Applying the Precautionary Principle to Gene Editing}

I recommend that we pause when the yellow light is flashing, but we proceed with our own gene driving. The yellow light should remind us of the PP, originally formulated for ecological ethics but equally applicable to genetics. Here is a UN working definition of the Precautionary Principle.

When human activities may lead to morally unacceptable harm that is scientifically plausible but uncertain, actions shall be taken to avoid or diminish that harm. Morally unacceptable harm refers to harm to humans or the environment that is threatening to human life or health, or serious and effectively irreversible, or inequitable to present or future generations, or imposed without adequate consideration of the human rights of those affected. The judgment of plausibility should be grounded in scientific analysis. Analysis should be ongoing so that chosen actions are subject to review. (UNESCO 2005, p. 14)

I prefer the so-called Wingspread version of the Precautionary Principle as it was formulated at the 1992 United Nations Conference on Environment and Development: "When an activity raises threats of harm to human health or the environment, precautionary measures should be taken even if some cause and effect relationships are not fully established scientifically. In this context the proponent of the process or product, rather than the public, should bear the burden of proof" (Urban Governance 1998). Although the PP applied originally to ecological ethics, I think it might apply equally well to gene editing.

The PP is a variation on the non-maleficence principle, because it opens a temporal space to explore the possibilities that harm might be done. But, exploring possibilities cannot go on indefinitely. At some point, researchers need to leap forward. The PP should be a temporary principle, whereas the Beneficence Principle-heal whenever the opportunity presents itself-should be permanent. Hence, "Yes, but not yet."

NASEM pauses at the yellow light, but then drives through. "Heritable germline genome editing trials must be approached with caution, but caution does not mean they must be prohibited (NASEM 2017, p. 102).

In short, when today's scientists engage in therapies that might yield consequences for generations to come, the burden of proof regarding safety must be borne now. Rather than march forward and risk falling off a cliff, the burden of proof requires that we locate as many of the cliffs as possible before marching. Invoking the PP is like looking both ways before proceeding through the yellow light.

\section{Public Contributions to Ethics}

Some concerned scientists, led by Edward Lanphier, president of Sangamo and chairman of the Alliance for Regenerative Medicine in Washington DC, speak out on both safety and the public's contribution. "In our view, genome editing in human embryos using current technologies could have unpredictable effects on future generations. This makes it dangerous and ethically unacceptable. Such research could be exploited for non-therapeutic modifications. We are concerned that a public outcry about such an ethical breach could hinder a promising area of therapeutic development, namely making genetic changes that cannot be inherited" (Lamphier et al. 2015). Note that such scientists provide two reasons for precaution. First, unpredictable consequences risk negative impact. This in 
itself warrants appeal to the PP. Second, scientists want to avoid offending the public who might shut off the supply of their research money for non-germline research. That is, "I'll be moral if you pay me to be." An appeal to gain public funding supplements the inherently ethical warrant, apparently.

Here is the hinge on which both the ethical and public image arguments swing: the distinction between genome editing in somatic cells and in germ cells. Virtually everyone would approve morally of therapeutic gene editing in somatic cells such as the cancer research mentioned above. But, germline cells should be treated as if they have laboratory leprosy. A voluntary moratorium in the scientific community could be an effective way to discourage human germline modification and raise public awareness of the difference between these two techniques. Such a moratorium would obey the PP while giving the public time to join the applause for our laboratory geneticists. But, if we are to declare a moratorium on germline gene editing, what will be our ethical argument?

Let me distinguish between the safety ethic and the ethical appeal to the Promethean anti-play-god position. They are not the same. Here is the safety argument: because of a foundational commitment to non-maleficence-do no harm!-medical researchers should pursue risk assessment to maximize protection of patient safety. If safety is put at too high a risk, then CRISPR editing should be postponed until that risk can be reduced. The mandate to protect safety through risk-assessment goes virtually unquestioned.

Nevertheless, this safety argument differs significantly from the Promethean argument against gene editing. The anti-play-god position puts a red stop light in front of Prometheus as well as Frankenstein in order to protect our inherited nature. If we violate nature, then nature will unleash punishment in the form of increased suffering. According to the anti-play-god argument, no amount of risk assessment can protect us from the self-destruction heaped upon us due to our hubris, our overreach into the sacred depths of nature. Let's examine the decisive assumption of this anti-play-god position, namely, nature as we have inherited it is sacred and should not be violated with technological alteration.

\section{Is the Human Genome Metaphysically Off-Limits to Gene Editing?}

Should we think of the human genome as sacred and unchangeable? "Is the human genome sacred? Does editing it violate the idea that we're made in God's image or, perhaps worse, allow us to 'play God'?" (Joseph 2016)

No. The human genome is not sacred, nor is it immoral to edit it (Peters 2003; Peters et al. 2008). Neither Prometheus nor Frankenstein should dictate our ethics. In the myth of Prometheus it is Zeus who punishes the Titan for stealing what belongs to the Olympian gods, whereas in the Frankenstein sequel nature replaces Zeus and exacts punishment against human hubris or pride. Should we today fear nature as the ancient Greeks feared Zeus?

No, because nature is not sacred, at least for biblical believers. "Creation is the work by which God establishes and sustains the existence of beings that are other than God," writes biblical scholar Ian McFarland (McFarland 2014, p. 107). Neither we human beings nor our genomes are divine, sacred, untransformable. In addition, as theologian Cynthia Crysdale (above) notes, God's creation is already changing and evolving with new things emerging. Nature is already on the move, so to speak. Therefore, no one violates the being of God let alone the created order through technological innovation. Moral values are formulated by ethicists in light of their vision of a future that is good for humanity and good for the encompassing creation. Neither Zeus nor nature should paralyze us with trepidation.

In short, there is no theological or metaphysical reason to presume that the genome we have inherited either individually or as a species is so sacred that we should put up a stop light saying, "Don't Change the Genome." DNA is not the essence of the human being, either individually or collectively. Altering the genome in our somatic cells for therapeutic reasons is akin to surgical removal of an infected appendix or implantation of a stent in the heart. If genome alteration improves health 
and wellbeing, then we should thank God for giving us the medical scientists who can provide this healing.

The bioethical issues raised by CRISPR/Cas9 are more practical than metaphysical or anthropological. Again, what is at stake is caution accompanied by scientific and technological advance.

\section{Gene Drive: A Yellow or Red Light?}

One prospect exciting futurists is the application of CRISPR/Cas9 technology to gene drive. Gene drive-promoting genetic changes to spread in a population in the absence of selective advantage-could become beneficial when controlling vector-borne disease such as malaria and for restoring an environment already threatened by a nonindigenous organism.

The CRISPR controversy reminds us that the other creatures with whom we humans share our planet have also become an ethical concern. We might consider invoking precaution regarding the possible environmental impact of removing from mosquitoes the capacity to spread malaria. On the one hand, we can anticipate future applause for eliminating the malaria, yellow fever, and Zika viruses. On the other hand, unless properly regulated and contained, this research has risk; it has the potential to rapidly alter our ecosystems in irreversible and damaging ways.

Proof-of-concept in a few laboratory studies to date is not sufficient to support a decision to release gene-drive modified organisms into the environment. The potential for gene drives to cause irreversible effects on organisms and ecosystems calls for a robust method to assess risks. A phased approach to testing, engagement of stakeholders and publics, and clarified regulatory oversight can facilitate a precautionary, step-by-step approach to research on gene drives without hindering the development of new knowledge. (NASEM 2016)

Proceed with constant risk-assessment. This is what the Precautionary Principle exacts on us, I believe.

\section{Objecting to the Precautionary Principle}

Some scientific researchers object to invoking PP because it appears to tie their hands. "Precautionary approaches to governance of emerging technology call for constraints on the use of technology whose outcomes are characterized by high levels of complexity and uncertainty" (Kaebnick et al. 2016, p. 710). Scientists and technology innovators are impatient with the PP because it threatens to paralyze development and use of even beneficial new technologies such as CRISPR. Invoking the PP too often takes the form of scaremongering. Can reasonable caution be made compatible with support for science? Why not?

A corollary objection is that PP is too vague (NASEM 2016; UNESCO 2005, p. 51). It's ambiguous. Defenders of PP counter by declaring that critics may be demanding more than PP can deliver. PP was never meant to provide an algorithm for decision-making. Rather, $\mathrm{PP}$ 's value is better understood as fostering an attitude, disposition, or cautious approach that includes sharpening or broadening the scrutiny of any proposed project.

In light of these objections and responses, I recommend we press for increased clarity regarding what PP intends. Distinguishing reasonable caution to avoid Promethean recklessness should not be all that difficult.

Bioethicists who invoke PP recognize that scientific progress does not advance in a vacuum. It functions within society, within the ecosphere. When it comes specifically to gene drive, PP advocates ask that authorities engage relevant publics and foster attention to values, questions, priorities, and safety concerns. In a democratic society, stakeholders require consultation. Further, ecological risk assessment regarding long term impact should precede the initial proposal for a technology such as gene drive (NASEM 2016). 
Some PP bioethicists want to slow the pace of technological development. Researchers should follow phased testing that monitors step-by-step progress. Researchers should advance to future phases only after gaining evidence regarding potential outcomes. It appears to me that invoking the PP at this stage of technological development should be evaluated on a case by case basis and not be thought of as a rule or policy.

\section{Conclusions}

Harvard entomologist E. O. Wilson gives the Promethean war cry-waving the technological imperative flag while trumpeting the positive Promethean war hoop-that causes bioethicists to shudder and cower in abject fear: "We are about to abandon natural selection, the process that created us, in order to direct our own evolution by volitional selection-the process of redesigning our biology and human nature as we wish them to be" (Wilson 2014, p. 14). Should this green light position prevail, one might expect the elimination of governmental regulations, IRBs, and bioethics committees. Such unbridled Promethean recklessness would lead only to reactive punishment, exacted not by Zeus but by nature, at least according to the prevailing myth.

How can today's bioethicist earn an honest living by protecting us from both the green light of the technological imperative and the anti-play-god red light while still fostering progress in human health and wellbeing? I offer four recommendations for both scientists and their ethicist friends.

First, encourage the scientific community to remain in the conversation regarding bioethics. Don't separate the professions. Ethicists must welcome those scientists-especially the NASEM scientists - who have already foreseen many of the ethical issues and are motivated to proceed with caution. The Promethean version of the technological imperative has not as of this writing overly contaminated CRISPR/Cas9 research, even though it is an ever present threat.

Second, bioethical research projects should be funded to examine long range impact of germline modification via CRISPR or other genome modification methods. Such specifically ethical research should incorporate up-to-date scientific findings along with the applicability of the Precautionary Principle, harm-benefit analysis, cost-benefit analysis, and such. Classical bioethical principles-non-maleficence, beneficence, autonomy, and justice-should provide the categories within which research results are reported.

Third, bioethicists should encourage the existing willingness within the scientific community to give serious consideration to the Precautionary Principle. Prudence-not the technological imperativeshould be our watchword here. Prudence with a yellow light should inform public policy and bioethics consultants. If the public is willing to withhold research money for genetic therapies, then researchers might become even more precautious regarding germline editing. Such a funding threat would have no impact on private business selling CRISPR-based services, however.

Fourth, ethicists and the supporting public should promote increased research into prognosticating the future impact on the environment and the wider ecosphere, i.e., continue research on risk assessment. Looking ahead is indispensable. We should look ahead before driving through the flashing yellow light.

In short, CRISPR/Cas9 puts us momentarily at a traffic stoplight. We have three options. The positive Promethean or transhumanist option is to race through a green light toward our post-human destination. The anti-play-god Promethean option is to hope that the light will remain red so all traffic remains stopped. The proceed-with-caution bioethicist looks both ways on yellow, but drives forward. I recommend the third.

Conflicts of Interest: The authors declare no conflict of interest. 


\section{References}

Annas, George J. 2016. The mythology of CRISPR. Science 354: 189. [CrossRef]

Caplan, Arthur L., Brendan Parent, Michael Shen, and Carolyn Plunkett. 2015. No time to waste-the ethical challenges created by CRISPR. Science and Society 16: 1421-26. [CrossRef]

Couzin-Frankel, Jennifer. 2016. Worries, confusion after cancer trial deaths. Science 354: 1211. [CrossRef] [PubMed]

Crysdale, Cnythia W. 2003. Playing God? Moral Agency in an Emergent World. Journal of the Society of Christian Ethics 23: 243-59. [PubMed]

Cyranoski, David. 2016. First trial of CRISPR in people. Nature 535: 476-77. [CrossRef] [PubMed]

Doudna, Jennifer A., and Emmanuelle Carpentier. 2014. Genome Editing: The new frontier of genome editing with CRISPR-Cas9. Science 346: 1258096. [CrossRef] [PubMed]

Eckman, Jim. 2015. The Ethics of Gene Editing. Issues in Perspective, May 16. Available online: https:// graceuniversity.edu/iip/2015/05/the-ethics-of-gene-editing/ (accessed on 28 November 2016).

Hefner, Philip. 1993. The Human Factor: Evolution, Culture, and Religion. Minneapolis: Fortress Press.

Herzfeld, Noreen L. 2002. In Our Image: Artificial Intelligence and the Human Spirit. Minneapolis: Fortress Press.

Joseph, Andrew. 2016. God and the genome: A geneticist seeks allies among the faithful. STAT, October 13. Available online: https:/ /www.statnews.com/2016/10/13/genome-religion-ethics-ting-wu/ (accessed on 28 November 2016).

Joy, Bill. 2000. Why the Future Doesn't Need Us. Wired, April. Available online: https:/ /www.wired.com/2000/ 04/joy-2/ (accessed on 28 November 2016).

Kaebnick, Gregory E., Elizabeth Heltman, James P. Collins, Jason A. Delborne, Wayne G. Landis, Keegan Sawyer, Lisa A. Taneyhill, and David E. Winickoff. 2016. Precaution and governance of emerging technologies. Science 354: 710-11. [CrossRef] [PubMed]

Kozubek, Jim. 2016. Modern Prometheus: Editing the Human Genome with CRISPR-Cas9. Cambridge: Cambridge University Press.

Lamphier, Edward, Fyodor Urnov, Sarah Ehlen Haecker, Michael Werner, and Joanna Smolenski. 2015. Don't Edit the Human Germline. Nature 521: 117. Available online: http:/ / www.nature.com/news/don-t-edit-thehuman-germline-1.17111 (accessed on 6 April 2017).

McFarland, Ian A. 2014. From Nothing: A Theology of Creation. Louisville: Westminster John Knox.

NASEM (National Academy of Science, Engineering, and Medicine). 2016. Gene Drives on the Horizon: Report in Brief. Available online: http://nas-sites.org/gene-drives/files/2015/08/Gene-Drives-Brief06.pdf (accessed on 28 November 2016).

NASEM (National Academy of Science, Engineering, and Medicine). 2017. Human Genome Editing: Science, Ethics, Governance. Washington: The National Academic Press (pre-publication).

Novella, Steven. 2015. CRISPR and the Ethics of Gene Editing. Science Based Medicine, December 2. Available online: https://www.sciencebasedmedicine.org/crispr-and-the-ethics-of-gene-editing/ (accessed on 28 November 2016).

PC Magazine. Encyclopedia: Technology imperative. Available online: www.pcmag.com/encyclopedia/term/ 64252/technology-imperative (accessed on 6 April 2017).

Peters, Ted. 2003. Playing God? Genetic Determinism and Human Freedom, 2nd ed. London and New York: Routledge.

Peters, Ted. 2005. Playing God. In Encyclopedia of Science, Technology, and Ethics, 4 vols; Edited by Carl Mitcham. New York: Thomson Gale, vol. 3, pp. 1424-27.

Peters, Ted, Karen Lebacqz, and Gaymon Bennett. 2008. Sacred Cells? Why Christians Should Support Stem Cell Research. New York: Roman and Littlefield.

Peters, Ted. 2017. God in Cosmic History: Where Science and History Meet Religion. Winona: Anselm.

Ramsey, Paul. 1970. Fabricated Man: The Ethics of Genetic Control. New Haven: Yale.

San Francisco Ballet. 2017. Encore. San Francisco: Encore Media Group, Program 3.

The President's Council on Bioethics. 2003. Beyond Therapy: Biotechnology and the Pursuit of Happiness. Available online: https://bioethicsarchive.georgetown.edu/pcbe/reports/beyondtherapy/fulldoc.html (accessed on 31 October 2016).

UNESCO (United Nations Educational, Scientific, and Cultural Organization). 2005. The Precautionary Principle. Available online: http://unesdoc.unesco.org/images/0013/001395/139578e.pdf (accessed on 15 December 2016). 
Urban Governance. 1998. Wingspread Statement on the Precautionary Principle. Available online: http:/ / www. gdrc.org/u-gov/precaution-3.html (accessed on 15 December 2016).

Verhey, Allen. 2005. What Makes Christian Bioethics Christian? Bible, Story and Communal Discernment. Christian Bioethics 11: 297-315. [CrossRef] [PubMed]

Wilson, Edward O. 2014. The Meaning of Human Existence. London: W.W. Norton.

Young, Simon. 2006. Designer Evolution: A Transhumanist Manifesto. Amherst: Prometheus Books.

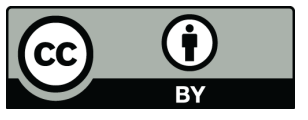

(c) 2017 by the author. Licensee MDPI, Basel, Switzerland. This article is an open access article distributed under the terms and conditions of the Creative Commons Attribution (CC BY) license (http://creativecommons.org/licenses/by/4.0/). 